\title{
Prolonged diatom blooms and microbial food web dynamics: experimental results from an Arctic polynya
}

\author{
Connie Lovejoy ${ }^{1, *}$, Louis Legendre ${ }^{1, * *}$, Neil M. Price ${ }^{2}$ \\ ${ }^{1}$ Québec-Océan (GIROQ), Department of Biology, Université Laval, Québec, Québec G1K 7P4, Canada \\ ${ }^{2}$ Department of Biology, McGill University, 1205 Avenue Docteur Penfield, Montréal, Québec H3A 1B1 Canada
}

\begin{abstract}
Thalassiosira spp., large-chain forming centric diatoms, typically dominate the biomass during phytoplankton blooms in the North Water Polynya $\left(76\right.$ to $79^{\circ} \mathrm{N}$, centred on ca. longitude $75^{\circ} \mathrm{W}$ ), which is the largest recurring polynya in the Canadian Arctic. We used an experimental method based on semi-continuous cultures to investigate mechanisms responsible for bloom maintenance and associated changes in microbial food web constituents. We compared 2 treatments: (1) a new nutrient system in which the cultures were partially enriched every $2 \mathrm{~d}$ with nutrient-rich seawater from depth to simulate horizontal or vertical advection, and (2) a recycled nutrient system in which large particles $(>2.0 \mu \mathrm{m})$ were partially removed every $2 \mathrm{~d}$ to simulate grazing and sinking losses without nutrient replacement. The experiment lasted $8 \mathrm{~d}$. In the new nutrient treatment, large diatoms, particularly Thalassiosira spp. and to a lesser extent Chaetoceros spp., consumed the added nutrients and continued to dominate production and biomass of the protist community. The total eukaryotic community production in the 'recycled' community shifted to one dominated by dinoflagellates and ciliates in the absence of diatom growth. These 2 end points corresponded to 2 types of communities observed in the North Water Polynya in June 1998. Net production rates for viruses and bacteria were not significantly different between treatments. These results demonstrate the importance of advective processes in maintaining a prolonged diatom bloom. An underlying microbial food web dominated by large $(>20 \mu \mathrm{m})$ ciliates and dinoflagellates was able to maintain similar rates of net production respective of new versus recycled nutrient supply. Dominance of the protist communities by large cells under both conditions is likely to favour the sustained high productivity of zooplankton and megafauna that characterize the North Water Polynya.
\end{abstract}

KEY WORDS: Diatom blooms $\cdot$ Ciliates $\cdot$ Dinoflagellates $\cdot$ Microbial food webs $\cdot$ New and recycled nutrients

Resale or republication not permitted without written consent of the publisher

\section{INTRODUCTION}

In many parts of the World Ocean, a spring bloom of diatoms is typically followed by a microbial food web dominated by other protists, including dinoflagellates, ciliates or a diverse array of flagellates. During the development and decline of the diatom bloom, particulate organic material (POM) may be grazed by proto-

Present addresses:

${ }^{*}$ Dept Biologia Marina i Oceanografia, Institut de Ciències del Mar, CMIMA, CSIC, Passeig Marítim de la Barceloneta 37-49, 08003 Barcelona, Spain.

E-mail: clovejoy@icm.csic.es

** Laboratoire d'Océanographie de Villefranche, BP 28, 06234

Villefranche-sur-Mer Cedex, France zoan or metazoan zooplankton (Levinsen et al. 1999, 2000a). Alternatively, POM, including phytoplankton, may sink out of the euphotic zone as individual cells, cellular aggregates or fecal pellets. Ultimately, the microbial community depends on dissolved organic material (DOM) and recycled nutrients that are released by cellular exudation, bacterial and viral activities and grazing (Azam et al. 1983). The timing and extent of diatom blooms prior to the community shifting to a microbial food web determine the fate of POM and DOM and have implications for carbon and nutrient recycling in the oceans (Azam 1998, Buesseler 1998, Anderson \& Ducklow 2001).

Interannual variability in the duration and composition of blooms is well documented. Complex hydro- 
graphic processes act to prolong or shorten the blooms in many regions (Koeve \& Ducklow 2001). Blooms typically end when nutrients are not replenished following stratification, and as particulate material sinks, the euphotic zone becomes biologically impoverished (Dale et al. 1999). Hydrographic processes that increase the rate of nutrient supply could contribute to maintaining production over long periods, but high supply rates are counterbalanced by high loss rates (advective horizontal or vertical export) due to dilution and transport out of the euphotic zone (Dutkiewicz et al. 2001). Evidence that communities can adjust to hydrographically driven high nutrient input and loss rate is seen in the persistent blooms associated with zones where 2 or more water masses intermingle (Landry et al. 2001, Morán et al. 2001).

Prolonged diatom blooms are a characteristic feature of some polynyas, ice-free regions surrounded by pack ice in polar seas. The largest polynya in the Canadian Arctic is the North Water Polynya (NOW) located between Ellesmere Island and Greenland. Early reports from this region drew attention to the high productivity at all trophic levels and its rich diatom flora (Grøntved \& Seidenfaden 1938). From April to July 1998, different regions and depths in the NOW were dominated by either diatoms or dinoflagellates and ciliates (Lovejoy et al. 2002a). Parallel studies showed that this was an area of active water mass interleaving (Melling et al. 2001, Bâcle et al. 2002) with regions of advective nutrient input (Tremblay et al. 2002). The water mass interleaving exerted an influence on protist community structure. High biomass layers dominated by diatoms were over- and underlain by ciliate and dinoflagellate-dominated communities. There was a highly significant correlation between variability in community structure throughout the water column and the extent of interleaving, indicating a strong physical influence on protist species dominance (Lovejoy et al. 2002b).

Despite the importance of protist community structure in affecting biogeochemical and trophic processes, there is still little understanding as to which factors determine species-specific blooms, or dominance by certain groups or species following a bloom (Wasmund et al. 1998, Cebréan \& Valiela 1999). The present study determined whether the alternate states of protistan dominance that are observed in the ocean (persistent diatom blooms vs microbial food web protists) could be selected for experiment when typical losses are imposed. We hypothesized that: (1) under advective conditions, diatom growth rates are able to keep pace with losses leading to persistent diatom blooms; and (2) under recycling conditions in which POM $>2.0 \mu \mathrm{m}$ is continuously lost but DOM and POM $<2.0 \mu \mathrm{m}$ are retained, dominance by dinoflagellates and ciliates is favoured.
We addressed these hypotheses by way of a shipboard experiment using seawater collected from a region of the NOW where a bloom had been ongoing over the previous month, but diatom biomass remained high despite depleted surface nutrients. As secondary objectives we evaluated to what extent advective versus recycling regimes affect macronutrient utilization, and the standing stocks and net production of other microbial food web constituents, specifically viruses, bacteria and nanoflagellates.

\section{MATERIALS AND METHODS}

Field sampling and experimental design. The NOW ( 76 to $79^{\circ} \mathrm{N}$, centred on longitude ca. $75^{\circ} \mathrm{W}$; extent ca. $80000 \mathrm{~km}^{2}$ ) was intensely sampled by the Canadian icebreaker Pierre Radisson between April and July 1998, as part of the International North Water Polynya Study. The NOW is primarily a latent heat polynya that occurs annually (Melling et al. 2001). In 1998, there was a persistent phytoplankton bloom (elevated chlorophyll a [chl a] levels and primary production) toward the western side of the polynya throughout June and into July (Mei et al. 2002). Water for the experiment was taken on 19 June 1998 from latitude $77^{\circ} 00.54^{\prime} \mathrm{N}$ and longitude $72^{\circ} 23.04^{\prime} \mathrm{W}$. (Stn 40 in Lovejoy et al. $2002 \mathrm{a}, \mathrm{b}$ ) from 9 and $200 \mathrm{~m}$ using a rosette sampler (General Oceanics) equipped with $10 \mathrm{l}$ Niskin type bottles and a Falmouth Scientific Instruments Integrated CTD. The $9 \mathrm{~m}$ water was randomly dispensed into autoclaved 2.51 Nalgene polycarbonate bottles after rinsing 3 times. Initial samples $\left(T_{i}\right)$ for nutrients, chl $a$, protist species identification and enumeration, and bacteria and viral concentrations were taken from the same cast. Four of the polycarbonate bottles, used as microcosms, were fitted with septum lids. Additional water collected at the same time from 9 and $200 \mathrm{~m}$ was filtered though $0.2 \mu \mathrm{m}$ Nuclepore filters to remove particles, bacteria and protists to prevent biological activity changing the nutrient characteristics of the water. This water was stored in autoclaved containers in the dark at $0^{\circ} \mathrm{C}$ and used over the course of the experiment (maximum $6 \mathrm{~d}$ storage) as outlined below. The 4 microcosm bottles were put into bags made of 2 layers of neutral density shade cloth, to simulate $36 \%$ surface irradiance $\left(24 \mathrm{~h} \mathrm{~d}^{-1}\right.$ at these latitudes). The microcosms were then placed in an on-deck incubator, where the temperature was maintained between -1 and $+1^{\circ} \mathrm{C}$ by a constant flow of surface seawater. Normal ship movement ensured constant motion, and the round containers moved freely within the incubator. All subsequent manipulations were done using sterile techniques at less than $2{ }^{\circ} \mathrm{C}$, and microcosms were subsampled after gently 

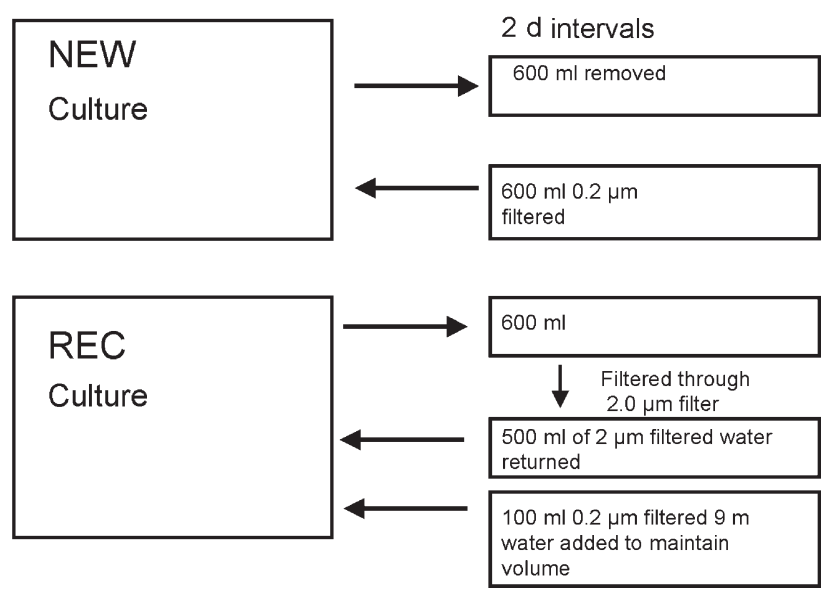

Fig. 1. Experimental set-up as described in the text. NEW: treatment with new nutrients from deep waters, REC: recycled treatment (see text)

inverting the containers 5 to 6 times. The loss rates imposed were similar to those in the natural environment (Hargrave et al. 2002).

The microcosms were first sampled after $36 \mathrm{~h}\left(T_{\mathrm{s}}\right)$ and then every $2 \mathrm{~d}$. Two experimental treatments were initiated based on recycled and new nutrients respectively (REC and NEW, Fig. 1). A total of $600 \mathrm{ml}$ was removed from each microcosm every $2 \mathrm{~d}$ as follows. For both treatments, $100 \mathrm{ml}$ was removed using a syringe through the septum lid. This subsample was used for nutrient analysis, protist identification and enumeration, and estimation of bacteria and virus-like particle (VLP) concentrations. Five hundred ml was then removed and filtered through $45 \mathrm{~mm}$ diameter, $2 \mu \mathrm{m}$ pore size Nuclepore PC membrane filters using an autoclaved Nalgene filter holder and receiver. This filter was frozen at $-20^{\circ} \mathrm{C}$ until chl a analysis onshore. In the REC treatment the $500 \mathrm{ml}$ of filtrate was returned to the same microcosm. The total volume was restored using $100 \mathrm{ml}$ of previously $0.2 \mu \mathrm{m}$-filtered water collected from $9 \mathrm{~m}$. In the NEW treatment, the $500 \mathrm{ml}$ of filtrate was discarded and the volume restored by adding $600 \mathrm{ml}$ of previously $0.2 \mu \mathrm{m}$-filtered nutrient-rich water collected from 200 m (new nutrients sensu Dugdale \& Goering 1967). At the end of the experiment, an additional $500 \mathrm{ml}$ was filtered through a Whatman GF/F filter for total chl a. Hereafter, $T_{\mathrm{i}}$ refers to the day when the initial sample was taken and water placed in bottles and $T_{\mathrm{s}}$ refers to the starting time of the experimental manipulations, $36 \mathrm{~h}$ later, when water was either replaced (NEW) or filtered and returned to the microcosms (REC).
As the experiment continued, $T_{\mathrm{s}+2}, T_{\mathrm{s}+4}$ and $T_{\mathrm{s}+6}$ refer to subsamples and manipulations 2,4 and $6 \mathrm{~d}$ after $T_{\mathrm{s}}$. $T_{\mathrm{s}+6}$ was the final day of the experiment.

Calculations. The net increase or decrease in the concentration $(C)$ of the measured state variables in the NEW treatments was calculated for each 2 d interval over the course of the experiment. Beyond $T_{\mathrm{s}}$, the net change was corrected for the removal and replacement of the culture with new media. For the first $36 \mathrm{~h}$ :

$$
\Delta C_{0, t+2}=C_{2}-C_{0}
$$

and for subsequent intervals:

$$
\Delta C_{t, t+2}=C_{t+2}-\left(1-\rho_{1}\right) C_{t}+\rho_{1} C_{\text {new }}
$$

where $C_{\text {new }}$ is the concentration in the replacement medium and $\rho_{1}$ is the $2 \mathrm{~d}$ dilution rate $(0.6 / 2.5=0.24)$. The net changes were then summed over the full $6 \mathrm{~d}$ period of the experiment to give a total cumulative production or loss expressed in concentration terms.

The same calculations were made for the REC treatments using Eq. (1) for the first interval and the following equation for the subsequent $2 \mathrm{~d}$ intervals:

$$
\Delta C_{t, t+2}=C_{t+2}-\left(1-\rho_{1}\right) C_{t}+\rho_{2} C_{a}+\rho_{3} C_{b}
$$

where $\rho_{2}=0.1 / 2.5$, with concentration $C_{a}$ (the initial $9 \mathrm{~m}$ water), and $\rho_{3}$ is the dilution rate for the filtered returned water $(0.5 / 2.5)$, with concentration $C_{b}$. For nutrients, VLP and bacteria, which passed through the $2.0 \mu \mathrm{m}$ filter, $C_{b}=C_{t i}$ for all the other components removed by filtration $C_{b}=0$. The $2 \mathrm{~d}$ increments or decrements were then summed to give total cumulative production or loss as for the NEW treatments. Nutrients were low in the initial $9 \mathrm{~m}$ sample (Table 1) compared to the $200 \mathrm{~m}$ water used in the NEW treatment, which was 16.53 and $1.37,14.89 \mu \mathrm{M}$ for nitrate, soluble reactive phosphorus (SRP) and silica respectively. VLP concentrations in the $200 \mathrm{~m}$ deep water were $1.3 \times 10^{9} \mathrm{l}^{-1}$, ca. one-fifth of the $9 \mathrm{~m}$ initial concentrations (Table 2). Since we removed potential viral hosts by filtration though a $0.2 \mu \mathrm{m}$ filter, we assumed that there was no viral production over the duration of the experiment. Initial ammonium concentrations were $<0.1 \mu \mathrm{M}$ for both 9 and $200 \mathrm{~m}$.

Table 1. Nutrient concentration $(\mu \mathrm{M})$ initially $\left(T_{\mathrm{i}}\right), 36 \mathrm{~h}$ later at the start of the separate treatments $\left(T_{\mathrm{s}}\right)$ and $6 \mathrm{~d}$ later $\left(T_{\mathrm{s}+6}\right)$ in the advective new nutrient (NEW) and recycled nutrient (REC) treatments. Values in parentheses are error estimates for replicate cultures

\begin{tabular}{|lcccc|}
\hline Day & Ammonium & Nitrate & SRP & Si \\
\hline$T_{\mathrm{i}}$ & $<0.1$ & 2.038 & 0.284 & 0.728 \\
$T_{\mathrm{s}}$ & $0.62(0.19)$ & $1.56(0.47)$ & $0.196(0.035)$ & $0.744(0.22)$ \\
$T_{\mathrm{s}+6} \mathrm{NEW}$ & $0.80(0.47)$ & $1.60(0.14)$ & $0.146(0.036)$ & $0.156(0.09)$ \\
$T_{\mathrm{s}+6}$ REC & $0.51(0.13)$ & $1.99(0.03)$ & $0.249(0.066)$ & $0.60(0.59)$ \\
\hline
\end{tabular}


Table 2. Biological variables, initially $(T \mathrm{i}), 36 \mathrm{~h}$ later at the start of the separate treatments $\left(T_{\mathrm{s}}\right)$ and $6 \mathrm{~d}$ later $\left(T_{\mathrm{s}+6}\right)$ in the advective new nutrient (NEW) and recycled nutrient (REC) treatments. Values in parentheses are SE for repli-

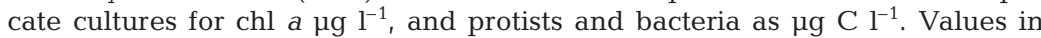
parentheses are error estimates for replicate cultures

\begin{tabular}{|lcccc|}
\hline Day & Chl $a$ & Bacteria & VLP $\times 10^{9} \mathrm{l}^{-1}$ & Protists \\
\hline$T_{\mathrm{i}}$ & 4.68 & 11.94 & 6.79 & 69.71 \\
$T_{\mathrm{s}}$ & $5.77(0.69)$ & $15.76(1.30)$ & $9.09(1.03)$ & $58.06(5.83)$ \\
$T_{\mathrm{S}+6} \mathrm{NEW}$ & $8.93(1.49)$ & $7.99(3.77)$ & $9.22(0.69)$ & $113.93(34.08)$ \\
$T_{\mathrm{s}+6}$ REC & $1.53(0.15)$ & $4.97(0.005)$ & $4.03(0.40)$ & $64.97(12.34)$ \\
\hline
\end{tabular}

Eukaryotic microbes. Phytoplankton and other protists were counted using a combination of fluorescence, Nomarski optics and Utermöhl sedimentation (FNU; Lovejoy et al. 1993). This method gives excellent agreement with total counts from the NOW using a membrane method, but provides much more taxonomic information (Lovejoy et al. 2002a). For this study, $45 \mathrm{ml}$ were sedimented for several weeks in $50 \mathrm{ml}$ Corning centrifuge tubes after which the top $40 \mathrm{ml}$ was carefully removed using a Pasteur pipette. The final $5 \mathrm{ml}$ was placed in a sedimentation chamber with DAPI $(0.0007$ $\mathrm{v} / \mathrm{v})$ and Calcofluor white $(0.001 \mathrm{v} / \mathrm{v})$ and resettled for $24 \mathrm{~h}$ prior to counting. DAPI was used to visualize the DNA within the nucleus and Calcofluor to stain cellulose and chitin for quick identification of thecate dinoflagellates and loricate Dinobryon spp. DAPI and Calcofluor fluoresce slightly different shades of blue under UV excitation (Zeiss Filter block 4877 02). Chl a in cells was confirmed under Zeiss filter block 487709 , and phycobilin in cryptophytes was verified using a green filter block (Zeiss 4877 15). The samples were counted at 200, 400 and $1000 \times$ magnification, using a Zeiss Axiovert 100 inverted microscope. Phytoplankton and other protists were identified to the lowest taxonomic level possible using light microscopy (see references in Lovejoy et al. 2002a). The error associated with this type of count data follows a Poisson distribution, and accuracy of the estimate of cells increases according to the square root of with the number of cells counted (Lund et al. 1958, Lund 1959). In total, 1000 to 8000 cells were counted for each sample, giving an overall error of 2.2 to $6.3 \%$. To minimize the accumulated error involved in estimating differences between communities we used biomass $\mathrm{C}$ values as suggested by Duarte et al. (1990). Cells were measured using both an ocular micrometer and images taken using a DageMTI CCD-300-RC video camera mounted on the Zeiss microscope and Metaview Software (Universal Imaging). The volumes were calculated from standard geometric shapes (Hillebrand et al. 1999) and carbon content estimated from relationships described in Menden-Deuer \& Lessard (2000).
Several taxa could not be routinely separated in the samples and therefore were grouped. For example, when large chain-forming centric diatoms grow rapidly, the cells become compact and tightly spaced, obscuring characteristics used to distinguish species (von Quillfeldt 2001). Consequently, we grouped Thalassiosira species, which primarily included $T$. antarctica var. borealis G. Fryxell, Douchett \& Q. Hubbard, T. hyalina (Grunow) Gran and T. bioculata (Grunow) Ostenfeld. The Thalassiosira grouping also probably included chains of Porosira glacialis (Grunow) Jørgensen. Phaeocystis were seen as both individual cells and as small colonies and may have been more than one species as well; in our wet mounts, we did not distinguish these further. Pyramimonas and Chrysochromulina are best identified by scale morphology using transmission electron microscopy, which was not done; almost certainly there were 2 or more species of these genera in the microcosms. Other protists with similar growth responses in the microcosms were grouped on functional criteria such as heterotrophic flagellates and large (40 to $100 \mu \mathrm{m})$ naked dinoflagellates.

Chl $\boldsymbol{a}$ and nutrients. Initial chl a samples were filtered onto Whatman GF/F filters and stored frozen. All chl a samples were later extracted ashore in boiling ethanol and measured fluorometrically using a Sequoia-Turner model 450 spectrofluorometer (Nusch 1980, Jeffrey \& Welschmeyer 1997). Water for nutrient analysis was collected into cryovials after being prefiltered through a $0.20 \mu \mathrm{m}$ Sartorius Minisart syringe filter; the first 3-4 ml of filtered water was discarded. Nitrate + nitrite (nitrate), SRP and silicate (Si), were analyzed on board the ship, using an ALPKEM autoanalyzer and colorimetric protocols (Grasshoff 1976). Ammonium concentrations were estimated immediately after collection of samples using the manual method given in Parsons et al. (1984).

Viruses. VLP were collected and enumerated using a modification of the Noble \& Fuhrman (1998) technique. Sample were preserved with a mixture of $0.2 \mu \mathrm{m}$ filtered glutaraldehyde and formaldehyde, which ensures good preservation of both protein structures and nucleic acids (Tsuji \& Yanagita 1981, Sommerville \& Scheer 1987). One ml of sample was filtered onto a $0.02 \mu \mathrm{m}, 25 \mathrm{~mm}$ diameter Whatman Anodisc filter, and stained with SYBR I and SYBR II green fluorophores that stain DNA and RNA, respectively (Molecular Probes). Each filter was mounted between a slide and cover slip using Aquapolymount (Polysciences). The slides were stored upright at $2^{\circ} \mathrm{C}$ for $24 \mathrm{~h}$ after which they were stored frozen until examination 
within 2 wk. The VLP were counted at 1000× under epifluorescence using a Zeiss Axiovert 10 microscope equipped with a blue filter block (Zeiss block 4877 09). For each sample 600 to 1000 VLP were counted. Since virus decay rates are normally shorter than the $2 \mathrm{~d}$ between the samplings used here (Weinbauer \& Suttle 1999), the net VLP production may have been systematically underestimated, but still useful for comparisons.

Bacteria. Samples for bacteria were preserved in $2 \%$ final concentration of electron microscope grade paraformaldehyde and stored in the dark at $2^{\circ} \mathrm{C}$ for up to $3 \mathrm{~d}$. The samples were stained with DAPI $(0.0007 \mathrm{v} / \mathrm{v}$ final concentration) for 20 to $30 \mathrm{~min}$ then filtered onto black $0.2 \mu \mathrm{m}$ Nuclepore PC membrane filters and mounted using Molecular Probes non-fluorescent mounting oil (Porter \& Feig 1980). The slides were frozen and bacteria counted within 1 to 4 wk after returning to shore, using a Zeiss Axiovert 10 microscope at $1000 \times$ magnification, with a UV filter block (Zeiss 4877 02). A total of 600 to 1000 bacterial cells were counted for each sample; some loss may have occurred during storage (Sherr \& Sherr 1993). The average ( \pm SE of the population) dimensions of bacteria were $0.72 \pm 0.27 \times 0.56 \pm 0.23 \mu \mathrm{m}$, calculated from halo corrected images using Metaveiw software ( $\mathrm{n}=400$

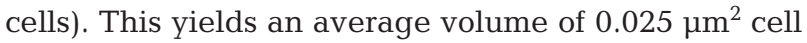
$\mathrm{I}^{-1}$. To facilitate comparisons with the literature a factor of $20 \mathrm{fg} \mathrm{C}$ cell $\mathrm{l}^{-1}$ was used to convert bacteria numbers to biomass carbon (Fuhrman 1992). We verified that there were few free bacteria retained on the $2.0 \mu \mathrm{m}$ filters used for the experimental treatments.

\section{RESULTS}

\section{Initial $36 \mathrm{~h}$}

At $T_{\mathrm{s}}, 36 \mathrm{~h}$ after collection, SRP and nitrate concentrations varied among the 4 microcosms (Table 1), with a drop in concentrations relative to $T_{\mathrm{i}}$ of 0.02 to $1.2 \mu \mathrm{M}$ nitrate, and 0.05 to $0.13 \mu \mathrm{M}$ SRP. Ammonium concentrations increased and ranged from 0.48 to 0.96 , so that total dissolved inorganic nitrogen increased slightly from 0.24 to $0.46 \mu \mathrm{MN}$. Although there was some variability between containers, Si concentrations remained relatively stable over this first $36 \mathrm{~h}$.

The initial protist community $\left(T_{\mathrm{i}}\right)$ was made up of ca. $70 \%$ biomass $\mathrm{C}$ as diatoms (Fig. 2). Thalassiosira spp. were dominant and represented $70 \%$ of the diatom biomass, equivalent to one-half of the total biomass $\mathrm{C}$. Bacterial concentrations were $0.6 \times 10^{9}$ cells $\mathrm{l}^{-1}$, and VLP ca. 10 times greater. The initial $9 \mathrm{~m}$ water was from a phytoplankton bloom with high chl $a$ and protist biomass (Table 2). After $36 \mathrm{~h}$, total biomass (protist +

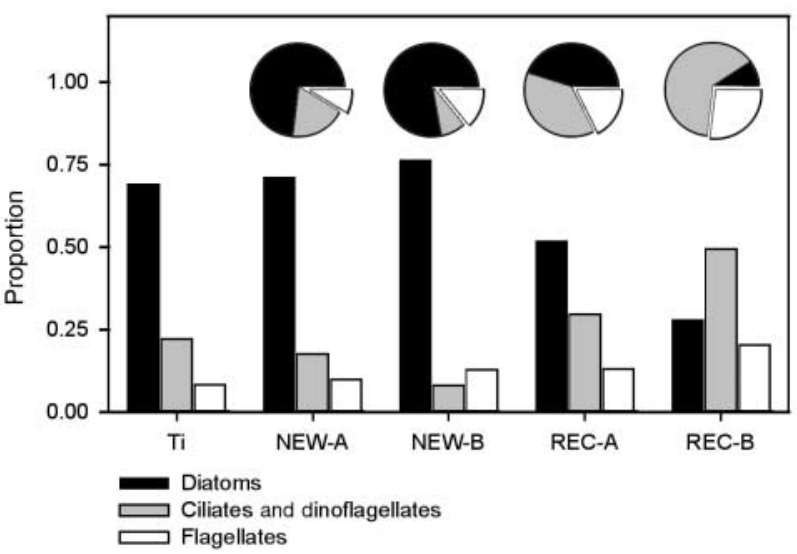

Fig. 2. Comparison of production (pie-diagrams) by the 3 principal functional groups: diatoms, alveolates (dinoflagellates and ciliates), and nanoflagellates (both phototrophic and heterotrophic) with initial community $\left(T_{\mathrm{i}}\right)$ and final community structure (bars). Results are shown for individual microcosms, designated A and B, for the 2 treatments, NEW and REC. The pie-diagrams are above their respective bar clusters and represent the proportional net production of the 3 protist groups over the $6 \mathrm{~d}$ of the experiment; the white slice is production by nanoflagellates

bacteria) remained at ca. $72 \mu \mathrm{gC} \mathrm{l}^{-1}$ (71.75 to $73.82 \mu \mathrm{g} \mathrm{C} \mathrm{l}^{-1}$; Table 2). However, this biomass had been redistributed with total protist biomass falling on average by ca.17\% and bacterial biomass increasing. Thalassiosira spp. continued to make up just under half of the total protist biomass. Average chl a concentrations had increased ca. $23 \%$. VLP concentrations were $33 \%$ greater than initially at $T_{\mathrm{i}}$.

\section{Experimental results}

The experimental intervention started at $T_{\mathrm{s}}$, with either removal of $24 \%$ of the $>2.0 \mu \mathrm{m}$ particles (REC treatment) or the removal and replacement of $24 \%$ of the 2.51 volume (NEW treatment); this was repeated every $2 \mathrm{~d}$ (Fig. 1). Ammonium concentrations in both treatments were similar at $T_{\mathrm{s}+4}$, with a mean $\pm \mathrm{SE}$ of $0.34 \pm 0.03$. At $T_{\mathrm{s}+6}$ concentrations varied among the 4 microcosms but there was no significant difference between the 2 treatments (Table 1). No data were available at $T_{\mathrm{s}+2}$. For the remaining nutrients, we tested for significant differences in net consumption over the course of the experiment (Table 3, significance reported only for variables where a significant effect was noted; p < 0.05; 2-way ANOVA, NEW and REC treatments and day sampled, $T_{\mathrm{s}+2}, T_{\mathrm{s}+4}$ and $T_{\mathrm{s}+6}$ ). Net nitrate, SRP and Si consumption were significantly greater in NEW versus REC treatments (Fig. 3a,b,c, respectively). In the NEW treatments, net consumption 
Table 3. Results from 2-way ANOVA. Treatment: NEW versus REC treatment; Day: sampling days $T_{\mathrm{s}+2}, T_{\mathrm{s}+4}$ and $T_{\mathrm{s}+6}$, see text for details; degrees of freedom: Treatment 1, Day 2, Treatment $\times$ Day 2, Residual 6. Variables: nitriate + nitrite (Nitrate), soluble reactive phosphate (SRP), silicate (Si), total eukaryotic biomsss C (Protists), chl a, bacterial biomass C (Bacteria). Thalassiosira C (Thalassiosira spp. and Porosira galcialis as biomass C) and Chaetoceros C (Chaetoceros spp. as biomass $\mathrm{C}$ ). Other variables tested but with no significant results are noted in the text (including others in Fig. 4)

\begin{tabular}{|lrrrrrrr|}
\hline \multirow{2}{*}{ Variable } & \multicolumn{9}{c}{ ANOVA statistics } \\
& \multicolumn{2}{c}{ Treatment } & \multicolumn{2}{c|}{ Day } & \multicolumn{2}{c|}{ Treatment $\times$ Day } \\
& $F$ & $\mathrm{p}$ & $F$ & $\mathrm{p}$ & $F$ & $\mathrm{p}$ \\
\hline Nitrate & 579.5 & $<0.001$ & 42.4 & $<0.001$ & 47.8 & $<0.001$ \\
$\mathrm{SRP}$ & 140.5 & $<0.001$ & 28.1 & $<0.001$ & 20.9 & 0.002 \\
$\mathrm{Si}$ & 405.5 & $<0.001$ & 78.0 & $<0.001$ & 79.5 & $<0.001$ \\
Chl a & 92.9 & $<0.001$ & 5.9 & 0.04 & 18.9 & 0.003 \\
Protists & 11.8 & 0.01 & 6.3 & 0.03 & 0.47 & 0.65 \\
Bacteria & 12.2 & 0.01 & 0.8 & 0.47 & 0.35 & 0.72 \\
Thalassiosira spp. & 10.2 & 0.02 & 2.7 & 0.14 & 1.3 & 0.335 \\
Chaetoceros spp. & 42.2 & $<0.001$ & 5.2 & $<0.049$ & 5.5 & 0.044 \\
& & & & & & & \\
\hline
\end{tabular}

the REC treatment, chl a production initially equalled losses up until the final day when there was net loss (Fig. 3d). Protist biomass increased with net accumulated production for both treatments, but with significantly greater production in the NEW compared to the REC treatment (Fig. 3e, Table 3).

There was an initial net accumulation of bacteria in the NEW treatment, but by the end of the experiment, production declined (Fig. 3f). In the REC treatment bacteria declined throughout the experiment. Overall, net accumulated bacterial production was greater in the NEW compared to the REC treatment (Table 3).

Diatoms were responsible for ca. $75 \%$ of net production in the NEW treatments whereas in the REC treatments alveowas greater than the supply rate so that final concentrations were below those at initial concentrations (Table 1). In the REC treatment (except for $\mathrm{Si}$ in 1 replicate) inorganic nutrients remained similar to starting conditions (Table 1) with no drawdown, hence no overall net consumption.

In the NEW treatment chl a increased over the duration of the experiment and net production was significantly greater than for the REC treatment (Table 3). In lates (dinoflagellates and ciliates) and to a lesser extent smaller ( 2 to $20 \mu \mathrm{m}$ ) flagellates contributed to the bulk of total production (Fig. 2). This net production by the various groups was reflected in final biomass values, with the proportion of diatoms in NEW treatments changing little from initial conditions (Fig. 2). Non-diatoms were responsible for 55 to $92 \%$ of the eukaryotic growth in the REC treatments, where net diatom growth was lower compared to that in the NEW treatment (Fig. 2).
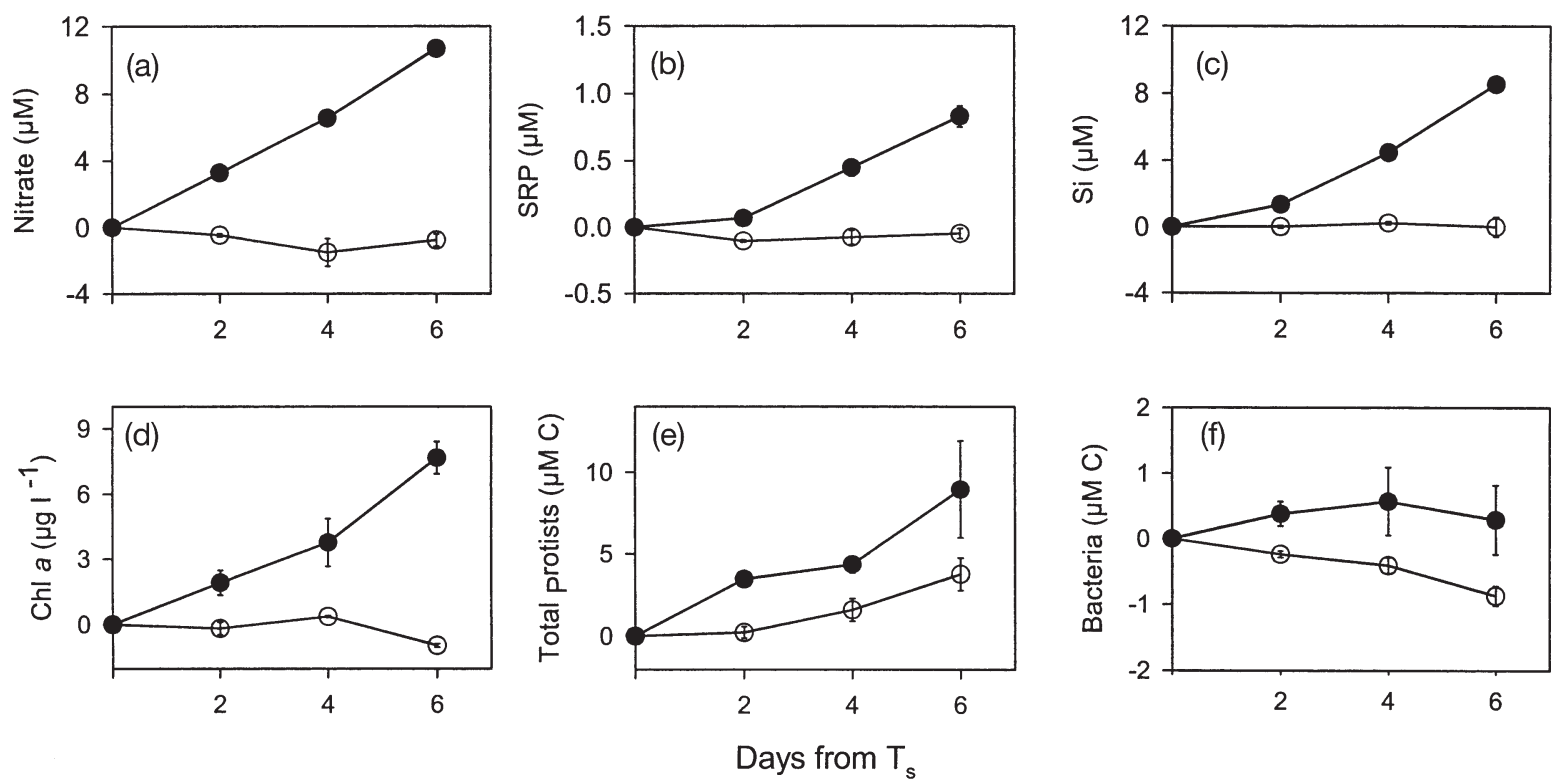

Fig. 3. $(\mathrm{a}-\mathrm{c})$ Net nutrient consumption over the $6 \mathrm{~d}$ following treatment intervention: (a) nitrate; (b) soluble reactive phospate (SRP); (c) silica (Si). (d-f) Net growth or loss of different biological variables: (d) chl $a_{i}$ (e) total protist biomass; (f) bacteria. Protists and bacteria are given in $\mu \mathrm{M} \mathrm{C}$ equivalent, to compare with nutrients. Means of the 2 replicate microcosms are shown; NEW: solid circles, REC: open circles; error bars are estimates of standard error of the population from the 2 replicate microcosms of each treatment, where error bars are smaller than symbol they are not shown 
Thalassiosira spp. dominated the diatom biomass in the initial sample and remained dominant throughout the experiment. In the NEW treatments, net growth of Thalassiosira spp. was greater than the dilution rate (Fig. 4a, Table 3). In the REC treatments, net growth was equivalent to the dilution rate, with the exception of the final sample in one of the REC treatments, where Thalassiosira spp. were responsible for the relatively high diatom biomass in the final REC-A treatment (Fig. 2). Another diatom group, Chaetoceros spp. (ca. $>80 \%$ hylochaetate spp.; C. socialis Lauder and C. furcellatus Bailey), showed a similar trend, with greater biomass accumulation in the NEW treatment (Fig. 4b, Table 3). For other diatoms (e.g. Pseudo-nitzschia spp. and Fragilariopsis spp.), there were no significant differences between the 2 treatments. We found no differences between treatments for other protist groups, including photosynthetic flagellates such as the prymnesiophytes Chrysochromulina spp. and Phaeocystis spp. (total accumulation, $0.48 \pm 0.18 \mu \mathrm{M} \mathrm{C}$, not shown). Net biomass accumulation by large heterotrophic dinoflagellates, including Gyrodinium pingue (Schütt) Kofoid \& Swezy, Gyrodinium spirale (Bergh) Kofoid \& Swezy, Gyrodinium pepo (Schütt) Kofoid \& Swezy and Gymnodinium gracile Bergh, was similar in both treatments (Fig. 4c).

Biomass accumulation by ciliates (Fig. 4d) and heterotrophic nanoflagellates (Fig. 4e), either taken as individual species or grouped, was also similar for both treatments. There were no treatment effects for VLP concentrations, which peaked on Day 2 and then dropped (Fig. 4f). There was a significant negative correlation between final nitrate and final chl a levels $\left(\mathrm{r}=0.97, \mathrm{p}=0.025\right.$, slope $\left.=-0.05 \mu \mathrm{MN} \mu \mathrm{g} \mathrm{chl} a^{-1}\right)$. No other significant relationships between the final biomass and nutrient concentrations were noted.

\section{DISCUSSION}

In the NEW nutrient treatment, the colonial centric diatoms Thalassiosira spp. and Chaetoceros spp. were the dominant genera. We were able to maintain high growth rates of Thalassiosira spp. using an advective culture technique over the $8 \mathrm{~d}$ of the experiment (Fig. 2). This community utilized added nutrients and overall net production was greater than the dilution rate. Thalassiosira spp. and Chaetoceros spp. are common dominants in polar waters (Wilson et al. 1986, Kang \& Fryxell 1993, Schloss \& Estrada 1994, Leventer \& Dunbar 1996, Andreassen \& Wassmann 1998). These 2 genera tend to be fast growing and opportunistic and quickly able to become dominant despite cold temperatures and variable light conditions (Lange et al. 1992, Wassmann et al. 1999, Agusti \& Duarte 2000, von Quillfeldt 2000). They were also dominant over the prolonged diatom bloom in the NOW, from late April to July 1998 (Booth et al. 2002, Lovejoy et al. 2002a).
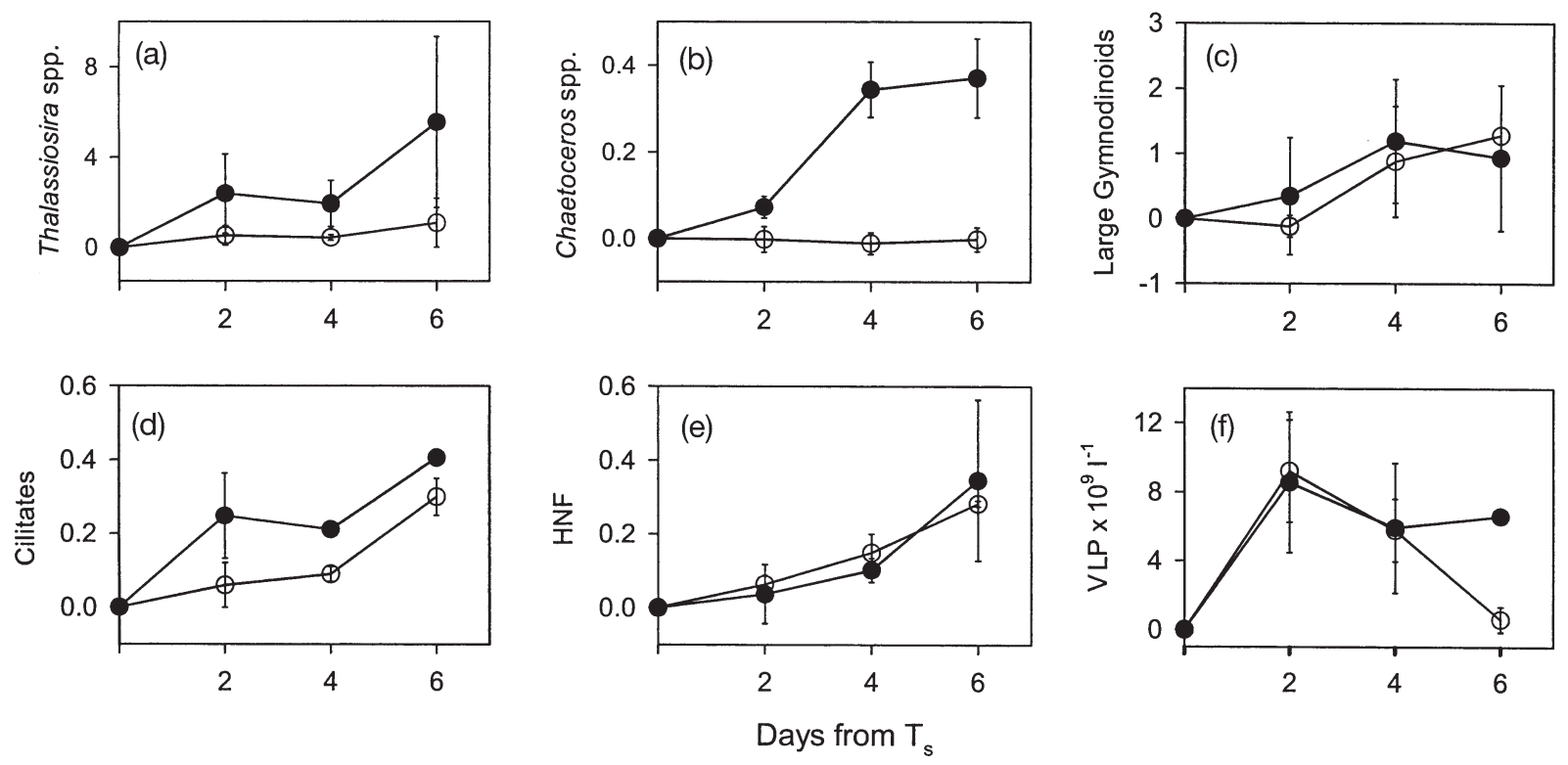

Fig. 4. Net growth or loss of different components of the protist community: (a) Thalassiosira spp., (b) Chaetoceros spp., (c) heterotrophic gymnodinoid dinoflagellates, (d) ciliates, (e) heterotrophic nanoflagellates (HNF) and (f) virus-like particles (VLP) particles $1^{-1}$. All but VLP are as $\mu \mathrm{MC}$ equivalents ( $\mu \mathrm{g} \mathrm{C} \mathrm{l}^{-1}$ divided by 12.01). Means of the 2 replicate microcosms are shown; NEW: solid circles, REC: open circles, error bars are estimates of standard error of the population from the 2 replicate microcosms of each treatment 
These 2 genera persisted especially in northern and western portions of the NOW where horizontal advective input of Arctic surface water is high (Bâcle et al. 2002). Our results indicate that continuous advective input of nutrients is likely to sustain the prolonged bloom of these centric diatoms in the NOW.

In the REC treatment, diatoms made up a decreasing percentage of the total protist production over the course of the experiment. Large-cell, diatom-dominated blooms are often short-lived phenomena that evolve into nanoplankton- and picoplankton-dominated communities as nutrients are drawn down and production becomes dependent on recycled nutrients (Azam et al. 1983, Scharek et al. 1994, Detmer \& Bathmann 1997). In the Southern Ocean, large diatoms dominate the ice edge blooms, but there is an underlying constant biomass of pico- (0.2 to $2 \mu \mathrm{m})$ and nanoplankton (2 to $20 \mu \mathrm{m}$ ) sized organisms (Detmer \& Bathmann 1997). This importance of either large diatoms or small cells was also noted in the Northeast Water Polynya, east of Greenland, as a mosaic of diatoms or nanoflagellates that dominated the autotrophic biomass (Booth \& Smith 1997). In contrast, several studies in the Canadian Arctic (Bursa 1961; Melville Bay) and West Greenland (Levinsen et al. 1999, 2000b; Disko Bay) have reported blooms of ciliates and dinoflagellates that directly follow diatom-dominated blooms. This phenomenon occurs in regions where protist grazing is primarily responsible for diatom losses (Nielsen \& Hansen 1995). On the eastern side of the NOW, phytoplankton production peaked in May (Mei et al. 2002), but the community continued to be dominated by large cells over the remainder of the season rather than becoming dominated by nano- and picoplankton. There is little Arctic inflow over this portion of the polynya (Bâcle et al. 2002) and the late season community is made up of ciliates and dinoflagellates (Lovejoy et al. 2002a), strikingly similar to that observed in the REC treatment (Fig. 2).

In summary we found that our experimental manipulations resulted in communities that mimicked those of the NOW, with either a diatom or a ciliate-dinoflagellate community. A successional sequence where larger microplankton (20 to $200 \mu \mathrm{m}$ ) sized cells persist in the upper water column contrasts with the more classic succession to microbial food webs dominated by nanoflagellates grazing on bacteria (Azam 1998). We found that in the experiments, as in the NOW, nano- and picoplankton-dominated communities were rare. Either unfavourable conditions for growth or loss rates in excess of growth may have caused the lack of dominance by small nanoflagellates in the post-bloom sequence in the NOW and in our recycled nutrient treatments.
The majority of nanoflagellates are either mixotrophic (Jones 1994) or heterotrophic (Vørs et al. 1995) and may be closely coupled to bacterial growth rates, implying that flagellates will do poorly in the absence of suitable prey (e.g. bacteria). In our experiments we found that over the first $36 \mathrm{~h}$ of incubation, before dilution of the cultures and when ambient nutrients were low, bacterial biomass increased slightly while total protist biomass fell. Bacteria have a greater demand for phosphorus compared to phytoplankton (Thingstad et al. 1998) and may be more efficient than phytoplankton at taking up $\mathrm{P}$ and $\mathrm{N}$ at low nutrient concentrations (Legendre \& Rassoulzadegan 1996). However, the average increase in bacterial biomass was only $0.32 \mu \mathrm{M}$, and assuming a $\mathrm{C}: \mathrm{P}$ ratio of 50 (Kirchman 2000) bacteria at most would have consumed $0.006 \mu \mathrm{M}$ $\mathrm{P}$ or ca. $7 \%$ (Table 1). In general, bacterial production is closely tied to the availability of suitable substrate (Anderson \& Ducklow 2001, Pomeroy \& Wiebe 2001), which implies that some DOM suitable for bacterial growth was available at the beginning of the experiment. However, bacteria production did not track photosynthetic protist production in the NEW treatment nor did bacteria dominate production in the REC treatment. Furthermore, bacterial production in the NEW treatment fell between $T_{\mathrm{s}+4}$ and $T_{\mathrm{s}+6}$ (Fig. 3f). Since the experimental protocol for both treatments would have acted to decrease grazing pressure on the bacteria by diluting grazing protists (Landry \& Hassett 1982, Gaul et al. 1999) bacterial growth appeared to be substrate limited over the remainder of the experiment. Similarly, Middelboe et al. (2002) found that postphytoplankton bloom bacterial production in the NOW was relatively low compared to other marine systems and that bacteria were substrate limited

Over the course of our observations by microscopy of natural and experimental samples, we noted that there were large and small flagellates as well as diatoms in the feeding vacuoles of ciliates and dinoflagellates, implying that the experimental dilution rate did not prevent protists grazing on other protists. This grazing pressure would further limit populations of smaller nanoflagellates. It is therefore likely that both poor bacterial growth and grazing by ciliates and dinoflagellates limited nanoflagellate production over the course of the experiment. It may be argued that lack of suitable organic substrates acted to limit both bacterial and nanoflagellate production in the NOW.

Viral activity may also have constrained bacterial production in these experiments by infection and lysis of bacterial cells. In the NEW treatment, where the deep water containing few VLP was added, infectious agents would be diluted relative to potential hosts. In the REC treatment, where the returned filtered water contained a full complement of viruses and bacteria, 
there would have been no dilution effect. Greater viral activity in the REC treatment would be consistent with differences in the net bacterial production between treatments (Fig 3f). Some DOM cycling may have occurred via the viral shunt (Wilhelm \& Suttle 1999), but this mechanism was not evaluated in the present study.

Final nutrient concentrations and community structure at $T_{\mathrm{s}+6}$ were a result of the total sum of events: initial conditions, light, and NEW versus REC nutrient and dilution regimes. The aim of current study was to understand community and species shifts that occur over time and space in an open system, typical of many marine environments (Montagnes et al. 1999, Joint et al. 2001). Over the first $36 \mathrm{~h}\left(T_{\mathrm{i}}\right.$ to $\left.T_{\mathrm{s}}\right)$ there was some divergence in nutrient consumption among the 4 starting microcosms, which meant that there was a range of starting conditions at $\mathrm{T}_{\mathrm{s}}$. However, the protist community did not change over this short period and diatoms were dominant in all 4 microcosms at $T_{\mathrm{s}}$. The lack of change over the first $36 \mathrm{~h}$ is consistent with the typical $3 \mathrm{~d}$ doubling times reported for polar phytoplankton and other protists (Smith et al. 1999) and $36 \mathrm{~h}$ was too short for a community shift to occur. By the end of the experiment there were significant differences between the treatments, indicating that the primary forcing variable on the community was from our treatments. A common criticism of mesocosms and microcosm experiments is that they induce artificial species shifts in phytoplankton and other protists that are due to bottle effects (Downing et al. 1999). In our experimental design we attempted to reduce this effect by using a semi-continuous culture protocol. This approach was successful in that protist species composition and nutrient concentrations in the replicates were similar over the course of the experiment with 1 exception, the final $\mathrm{Si}$ concentration in one of the REC microcosms was high. The increased dissolved Si in that instance was perhaps due to remineralization of the particulate $\mathrm{Si}$ pool (Bidle \& Azam 2001).

In the NEW treatment, diatom production increased (Fig. 2), communities took up all nutrients at a rate that matched or exceeded supply (Fig. 3a-d) and final nutrient concentrations were below initial concentrations. Ciliates, dinoflagellates and most nanoflagellates had similar production rates in the NEW and REC treatments, implying that these organisms were able to maintain productivity under a broad range of conditions (Fig. 4c-e). Production in the absence of nutrient input indicated efficient nutrient recycling by the community, with sufficient internal nutrient stores for the dinoflagellate-ciliate community to continue growth at least for 6 to $7 \mathrm{~d}$. Mei et al. (2002) found that over much of the polynya in June, ca. $30 \%$ of the inorganic carbon fixed was released as DOC. While direct measures of
DOM were not made DOC is part of the DOM pool. The $24 \mathrm{~h}$ light conditions likely enhanced DOM release (Lomas et al. 2000). In addition to viral activity discussed previously, grazing by heterotrophic protists (ciliates and dinoflagellates) on phytoplankton results in DOM release (Goldman et al. 1985) and would supply both DON and ammonium for the community (Ward \& Bronk 2001).

Large (40 to $100 \mu \mathrm{m}$ ) heterotrophic Gymnodinium spp. and Gyrodinium spp. are frequent, but numerically rare members of the marine planktonic community (Lessard 1991). We earlier found that they were species dominants along with ciliates at some depths and regions in the NOW (Lovejoy et al. 2002b). Both of these groups are active phytoplankton grazers (Bursa 1961), and at another site off the coast of Eastern Greenland, Nielsen \& Hansen (1995) reported that protist grazing on spring bloom diatoms was 3 times greater than grazing by copepods. In general, early grazing by protists would serve to keep POC in the water column over long time scales. This would also prolong the availability of the initial spring bloom for other trophic levels, as large cells would be readily available to macrozooplankton grazers (Stoecker \& Capuzzo 1990).

The NOW and its rich megafauna is the site of the northernmost indigenous human settlements in North America and Greenland, which is evidence that the region is a long-term stable productive ecosystem (Stirling 1997). Despite nutrient drawdown and high macrozooplankton production (Ringuette et al. 2002), phytoplankton biomass and production continues much longer over the summer season compared to other polar marine systems. This oasis of production is in stark contrast to more typical Arctic phytoplankton blooms, which rapidly end following nutrient exhaustion (Wassmann et al. 1999, von Quillfeldt 2000, Yager et al. 2001). Our experimental results here indicate that continuous advective nutrient supply in combination with continuous light is likely to favour prolonged blooms of Thalassiosira spp. and Chaetoceros spp., and that following water column stratification recycled nutrients sustain communities of large dinoflagellates and ciliates. In both cases, the persistent dominance by large-celled protists differs form other polar regions (Booth \& Horner 1997, Detmer \& Bathmann 1997, Reay et al. 2001) and is likely to ensure a continuous supply of excellent food for zooplankton (Atkinson 1996, Levinsen et al. 2000a) that in turn support large marine animals. Heterotrophic activity in this food web dominated by larger organisms is not linked to bacterial production, and thus also has broad implications for carbon cycling, for example by diminishing the proportion of carbon recycled within a tight microbial loop (Anderson \& Ducklow 2001). 
Acknowledgements. This paper is a contribution to International North Water Polynya Study led by Dr. Louis Fortier and funded by the Natural Sciences and Engineering Research Council of Canada (NSERC) and the Department of Fisheries and Oceans Canada. NSERC and Fonds FCAR Québec also provided support for GIROQ (Groupe interuniversitaire de recherches océanographiques du Québec) and to L.L. and N.M.P. C.L. was supported by NSERC postgraduate fellowships throughout the study. Thanks are extended to the captain and crew of the CCGS 'Pierre Radisson' for logistical support, C. D. Payne for chemical analyses and to M. Roberts and others for help in the field. Special thanks are due to C. H. von Quillfeldt, B. Booth and H. A. Thomsen for valuable discussions. We also thank B. Hargrave, W. F. Vincent and 3 anonymous reviewers for comments and suggestions on the manuscript.

\section{LITERATURE CITED}

Agusti S, Duarte CM (2000) Experimental induction of a large phytoplankton bloom in Antarctic coastal waters. Mar Ecol Prog Ser 206:73-85

Anderson TR, Ducklow HW (2001) Microbial loop carbon cycling in ocean environments studied using a simple steady-state model. Aquat Microb Ecol 26:37-49

Andreassen IJ, Wassmann P (1998) Vertical flux of phytoplankton and particulate biogenic matter in the marginal ice zone of the Barents Sea in May 1993. Mar Ecol Prog Ser 170:1-14

Atkinson A (1996) Subantarctic copepods in an oceanic, low chlorophyll environment: Ciliate predation, food selectivity and impact on prey populations. Mar Ecol Prog Ser 130: 85-96

Azam F (1998) Microbial control of oceanic carbon flux: the plot thickens. Science 280:694-696

Azam F, Fenchel T, Field JG, Gray JS, Meyer-Reil LA, Thingstad F (1983) The ecological role of water-column microbes in the sea. Mar Ecol Prog Ser 10:257-263

Bâcle J, Carmack EC, Ingram RG (2002) Water mass structure and circulation under the North Water Polynya during spring transition: April-July, 1998. Deep Sea Res II (in press)

Bidle KD, Azam F (2001) Bacterial control of silicon regeneration from diatom detritus: significance of bacterial ectohydrolases and species identity. Limnol Oceanogr 46: 1606-1623

Booth BC, Horner RA (1997) Microalgae on the Arctic Ocean Section, 1994: species abundance and biomass. Deep-Sea Res II 44:1607-1622

Booth BC, Smith WO Jr (1997) Autotrophic flagellates and diatoms in the Northeast Water Polynya, Greenland: summer, 1993. J Mar Syst 10:241-261

Booth BC, Larouche P, Bélanger S, Amiel D, Klein B, Mei ZP (2002) Dynamics of Chaetoceros socialis blooms in the North Water Polynya, Baffin Bay, Canada. Deep Sea Res II (in press)

Buesseler KO (1998) The decoupling of production and particulate export in the surface ocean. Global Biogochem Cycles 12:297-310

Bursa AS (1961) The annual oceanographic cycle at Igloolik in the Canadian Arctic II. The phytoplankton. J Fish Res Board Can 18:561-615

Cebréan J, Valiela I (1999) Seasonal patterns in phytoplankton biomass in coastal ecosystems. J Plankton Res 21: 429-444

Dale T, Rey F, Heimdal BR (1999) Seasonal development of phytoplankton at a high latitude oceanic site. Sarsia 84 419-435

Detmer AE, Bathmann UV (1997) Distribution patterns of autotrophic pico- and nanoplankton and their relative contribution to algal biomass during spring in the Atlantic sector of the Southern Ocean. Deep-Sea Res II 44:299-320

Downing JA, Osenberg CW, Sarnelle O (1999) Meta-analysis of marine nutrient-enrichment experiments: variation in the magnitude of nutrient limitation. Deep-Sea Res II 46: $1511-1530$

Duarte CM, Marrasé C, Vaqué D, Estrada M (1990) Counting error and the quantitative analysis of phytoplankton communities. J Plankton Res 12:295-304

Dugdale RC, Goering JJ (1967) Uptake of new and regenerated forms of nitrogen in primary productivity. Limnol Oceanogr 12:196-206

Dutkiewicz S, Follows M, Marshall J, Gregg WW (2001) Interannual variability of phytoplankton abundances in the North Atlantic. Deep-Sea Res II 48:2323-2344

Fuhrman JA (1992) Bacterioplankton role in recycling of organic matter. In: Falkawski PG, Woodhead AD (eds) Primary productivity and biogeochemical cycles in the sea. Plenum Press, New York, p 361-383

Gaul W, Antia AN, Koeve W (1999) Microzooplankton grazing and nitrogen supply of phytoplankton growth in the temperate and subtropical northeast Atlantic. Mar Ecol Prog Ser 189:93-104

Goldman JC, Caron DA, Andersen OK, Dennett MR (1985) Nutrient cycling in a microflagellate food chain: I. Nitrogen dynamics. Mar Ecol Prog Ser 24:231-242

Grasshoff K (1976) Methods of seawater analyses. Weinheim, New York

Grøntved J, Seidenfaden G (1938) The Godthaab Expedition 1928. The phytoplankton of the waters west of Greenland Meddelelser om Grønland, Band 82, No. 5. Kommissionen for videnskabelige undersøgelser i Grønland, Copenhagen, $\mathrm{p} 1-380$

Hargrave BT, Walsh ID, Murray DW (2002) Seasonal and spatial patterns in mass and organic matter sedimentation in the North Water Polynya. Deep-Sea Res II (in press)

Hillebrand H, Dürselen CD, Kirschtel D, Pollingher U, Zohary $\mathrm{T}$ (1999) Biovolume calculation for pelagic and benthic microalgae. J Phycol 35:403-424

Jeffrey SW, Welschmeyer NA (1997) Spectrophotometric and fluorometric equations in common use in oceanography. In: Jeffery SW, Mantoura RFC, Wright SW (eds) Phytoplankton pigments in oceanography. Monographs on oceanographic methodology. SCOR UNESCO Publishing, Paris, p 597-615

Joint I, Williams PJLeB, Savidge G (2001) Comparisons of plankton at $59^{\circ} \mathrm{N}$ during two Lagrangian drift experiments in the North Atlantic in June and July 1996. DeepSea Res II 48:1043-1061

Jones RI (1994) Mixotrophy in planktonic protists as a spectrum of nutritional strategies. Mar Microb Food Webs 8: $87-96$

Kang SH, Fryxell GA (1993) Phytoplankton in the Weddell Sea, Antarctica: composition, abundance and distribution in water-column assemblages of the marginal ice-edge zone during austral autumn. Mar Biol 116:335-348

Kirchman D (2000) Microbial ecology of the oceans. Wiley, New York

Koeve W, Ducklow HW (2001) JGOFS synthesis and modeling: the North Atlantic Ocean. Deep-Sea Res II 48: 2141-2151

Landry MR, Hassett RP (1982) Estimating the grazing impact of marine micro-zooplankton. Mar Biol 67:283-288 
Landry MR, Brown SL, Selph KE, Abbott MR, Letelier RM, Christensen S, Bidigare RR, Casciotti K (2001) Initiation of the spring phytoplankton increase in the Antarctic polar front zone at $170^{\circ} \mathrm{W}$. J Geophys Res 106:13903-13915

Lange CB, Hasle GR, Syvertsen EE (1992) Seasonal cycle of diatoms in the Skagerrak, North Atlantic, with emphasis on the period 1980-1990. Sarsia 77:173-187

Legendre L, Rassoulzadegan F (1996) Food-web mediated export of biogenic carbon in oceans: hydrodynamic control. Mar Ecol Prog Ser 145:179-193

Lessard EJ (1991) The trophic role of heterotrophic dinoflagellates in diverse marine environments. Mar Microb Food Webs 5:49-58

Leventer A, Dunbar RB (1996) Factors influencing the distribution of diatoms and other algae in the Ross Sea. J Geophys Res 101:18489-18500

Levinsen H, Nielsen TG, Hansen BW (1999) Plankton community structure and carbon cycling on the western coast of Greenland during the stratified summer situation. II. Heterotrophic dinoflagellates and ciliates. Aquat Microb Ecol 16:217-232

Levinsen H, Turner JT, Nielsen TG, Hansen BW (2000a) On the trophic coupling between protists and copepods in arctic marine ecosystems. Mar Ecol Prog Ser 204:65-77

Levinsen H, Nielsen TG, Hansen BW (2000b) Annual succession of marine pelagic protozoans in Disko Bay, West Greenland, with emphasis on winter dynamics. Mar Ecol Prog Ser 206:119-134

Lomas MW, Rumbley CJ, Glibert PM (2000) Ammonium release by nitrogen sufficient diatoms in response to rapid increases in irradiance. J Plankton Res 22:2351-2366

Lovejoy C, Vincent WF, Frenette JJ, Dodson JJ (1993) Microbial gradients in a turbid estuary: application of a new method for protozoan community analysis. Limnol Oceanogr 38:1295-1303

Lovejoy C, Legendre L, Martineau MJ, Bâcle J, von Quillfeldt $\mathrm{CH}$ (2002a) Distribution of phytoplankton and other protists in the North Water Polynya. Deep-Sea Res II (in press)

Lovejoy C, Carmack EC, Price NM, Legendre L (2002b) Water column interleaving: a new physical mechanism determining protist communities and bacterial states. Limnol Oceanogr 47:(in press)

Lund JWG, Kipling C, LeCren D (1958) The inverted microscope method of estimating algal numbers and the statistical basis of estimations by counting. Hydrobiologia 9: $143-170$

Lund JWG (1959) A simple counting chamber for nanoplankton. Limnol Oceanogr 4:57-65

Mei ZP, Legendre L, Gratton Y, Tremblay JÉ and 8 others (2002) Physical control of spring-summer phytoplankton dynamics in the North Water Polynya, April-July 1998. Deep-Sea Res II (in press)

Melling H, Gratton Y, Ingram RG (2001) Ocean circulation within the North Water Polynya of Baffin Bay. Atmos Ocean 39:301-325

Menden-Deuer S, Lessard EJ (2000) Carbon to volume relationships for dinoflagellates, diatoms and other protist plankton. Limnol Oceanogr 45:569-579

Middelboe M, Nielsen TG, Bjørnsen PK (2002) Viral and bacterial production in the North Water polynya: in situ measurements, batch culture experiments and characterization and distribution of a virus-host system. Deep-Sea Res II (in press)

Montagnes DJS, Poulton AJ, Shammon TM (1999) Mesoscale, finescale and microscale distribution of micro- and nanoplankton in the Irish Sea, with emphasis on ciliates and their prey. Mar Biol 134:167-179
Morán XAG, Taupier-Letage I, Váquez-Domingues E, Ruiz S, Arin L, Raimbault P, Estrada M (2001) Physical-biological coupling in the Algerian Basin (SW Mediterranean): influence of mesoscale instabilities on the biomass and production of phytoplankton and bacterioplankton. Deep-Sea Res I 48:405-437

Nielsen TG, Hansen B (1995) Plankton community structure and carbon cycling in Arctic West Greenland during and after the sedimentation of a diatom bloom. Mar Ecol Prog Ser 125:205-216

Noble RT, Fuhrman JA (1998) Use of SYBR Green I for rapid epifluorescence counts of marine viruses and bacteria. Aquat Microb Ecol 14:113-118

Nusch EA (1980) Comparison of different methods for chlorophyll and phaeopigment determination. Ergeb Limnol 14: $14-36$

Parsons TR, Maita Y, Lalli CM (1984) A manual of chemical and biological methods for seawater analysis. Pergamon Press, Oxford

Pomeroy LR, Wiebe WJ (2001) Temperature and substrates as interactive limiting factors for marine heterotrophic bacteria. Aquat Microb Ecol 23:187-204

Porter KG, Feig YS (1980) The use of DAPI for identifying and counting aquatic microflora. Limnol Oceanogr 25: 943-948

Reay DS, Priddle J, Nedwell DB, Whitehouse, Ellis-Evans JC, Deubert C, Connelly DP (2001) Regulation by low temperature of phytoplankton growth and nutrient uptake in the Southern Ocean. Mar Ecol Prog Ser 219:51-64

Ringuette M, Fortier L, Fortier M, Runge J, Bélanger S, Larouche P, Weslawski JM, Kwasniewski S (2002) Advanced recruitment and accelerated population development in Arctic calanoid copepods of the North Water. Deep-Sea Res II (in press)

Scharek R, Smetacek V, Fahrbach E, Gordon LI, Rohardt G, Moore S (1994) The transition from winter to early spring in the eastern Weddell Sea, Antarctica: plankton biomass and composition in relation to hydrography and nutrients. Deep-Sea Res I 4:231-1250

Schloss I, Estrada M (1994) Phytoplankton composition in the Weddell-Scotia confluence area during austral spring in relation to hydrography. Polar Biol 14:77-90

Sherr EB, Sherr BF (1993) Preservation and storage of samples for enumeration of heterotrophic protists. In: Kemp P, Sherr B, Sherr E, Cole J (eds) Current methods in aquatic microbial ecology. Lewis Publications, New York, p 207-212

Smith WO Jr, Nelson DM, Mathot S (1999) Phytoplantkon growth rates in the Ross Sea, Antarctica, determined by independent methods: temporal variations. J Plankton Res 21:1519-1536

Sommerville J, Scheer U (1987) Electron microscopy in molecular biology. IRL Press, Oxford

Stirling I (1997) The importance of polynyas, ice edges, and leads to marine mammals and birds. J Mar Syst 10:9-21

Stoecker DK, Capuzzo JM (1990) Predation on Protozoa: its importance to zooplankton. J Plankton Res 12:891-908

Thingstad TF, Zweifel UL, Rassoulzadegan F (1998) P limitation of heterotrophic bacteria and phytoplankton in the northwest Mediterranean. Limnol Oceanogr 43:88-94

Tremblay JÉ, Gratton Y, Carmack EC, Payne CD, Price NM (2002) Impact of the large-scale Arctic circulation and the North Water Polynya on nutrient inventories in Baffin Bay. $\mathrm{J}$ Geophys Res (in press)

Tsuji T, Yanagita T (1981) Improved fluorescent microscopy for measuring the standing stock of phytoplankton including fragile components. Mar Biol 64:207-211 
von Quillfeldt CH (2000) Common diatom species in Arctic spring blooms: their distribution and abundance. Bot Mar 43:499-516

von Quillfeldt CH (2001) Identification of some easily confused common diatom species in Arctic spring blooms. Bot Mar 44:375-389

Vørs N, Buck KR, Chavez FP, Eikrem W, Hansen LE, Østergaard JB, Thomsen HA (1995) Nanoplankton of the equatorial Pacific with emphasis on the heterotrophic protists. Deep-Sea Res II 42:585-602

Ward BB, Bronk DA (2001) Net nitrogen uptake and DON release in surface waters: importance of trophic interactions implied from size fractionation experiments. Mar Ecol Prog Ser 219:11-24

Wasmund N, Nausch G, Matthäus W (1998) Phytoplankton spring blooms in the southern Baltic Sea-spacio-temporal development and long-term trends. J Plankton Res 20: 1099-1117

Editorial responsibility: Fereidoun Rassoulzadegan, Villefranche-sur-Mer, France
Wassmann P, Ratkova T, Andreassen I, Vernet M, Pedersen G, Rey F (1999) Spring bloom development in the Marginal Ice Zone and the Central Barent Sea. PSZN I: Mar Ecol 20:321-346

Weinbauer MG, Suttle CA (1999) Lysogeny and prophage induction in coastal and offshore bacterial communities. Aquat Microb Ecol 18:217-225

Wilhelm SW, Suttle CA (1999) Viruses and nutrient cycles in the sea-viruses play critical roles in the structure and function of aquatic food webs. Bioscience 49:781-788

Wilson DL, Smith WO Jr, Nelson DM (1986) Phytoplankton bloom dynamics of the western Ross Sea ice edge. 1. Primary productivity and species-specific production. Deep-Sea Res 33:1375-1387

Yager PL, Connelly TL, Mortazavi B, Wommack KE, Bano N, Bauer JE, Opsahl S, Hollibaugh JT (2001) Dynamic bacterial and viral response to an algal bloom at subzero temperatures. Limnol Oceanogr 46:790-801

Submitted: February 25, 2002; Accepted: June 4, 2002 Proofs received from author(s): October 1, 2002 